\title{
NEW SPECIES OF LAMPYRIDA, INCLUDING A
}

\section{NOTICE OF THE MT. WILSON FIRE-FLY.}

\author{
By A. Sidney Olliff, F.E.S. \\ Assistant Zoologist, Australian Museum.
}

The insects commonly known as fire-flies in Australia belong to the family Lampyridx, and as I am not aware that any luminous species of Coleoptera belonging to other families have yet been discovered here, I believe to that family exclusively. Some authors who have treated of light-giving insects-as, for instance, the late Andrew Murray-confine the name fire-fly to the luminous Elateridæ or Click-beetles, and use the term glowworm for the Lampyridæ; but as this is opposed to the practice of a large number of entomologists, and to the every-day habit of those who live in the localities where the insects are found, I do not propose to adopt the terms in this sense, especially as it appears to me a better course to apply the name fire-fly to winged forms of whatever family, and to confine the name glow-worm to those, whether larvæ or wingless females, which are found on the ground. The cause of the phosphorescence or luminosity which gives these insects their names was long wrapt in mystery, and many were the speculations indulged in by the older naturalists as to its use and origin. Nearly all recent writers, however, have agreed that the light which they emit is a means of attracting the sexes to each other; whence the oft-quoted lines applied by the poet Montgomery to the female glow-worm, which is said

" To captivate her favourite fly, And tempt the rover through the dark."

From the labours of de Bellesme $*$ and Wielowiejski, $\uparrow$ with regard to the cause of the luminosity, it appears to be fairly

* Comp. Rend, xc., p. 318 ; also Ann. Mag. Nat. Hist. (5), v., p. 345 (1880).

† Z. Wiss. Zool. xxxvii. p. 354, (1882). 
established that the light is produced by the slow oxidation or combustion of a substance supposed to be phosphoretted hydrogen, which is formed under the influence of the nervous system, and that the seat of light is the parenchymatous cells of the superficial layer of the light-organs, and not in the terminations of the tracheæ which thickly traverse them. These conclusions are borne out by the experiments of Emery, ${ }^{*}$ who states that when the luminosity is only at half its full power the combustion is exclusively confined to these cells. It is only necessary to allude to the power possessed by these insects of extinguishing their light at will, $\dagger$ a power which they can only exercise for a short period, probably just so long as the air can be shut away from the abdominal light-organs; but I should like to add a few remarks concerning the external appearance of the light of the species here called Atyphella lychnus, which I had an opportunity of observing in the garden of Mr. E. C. Merewether when visiting Mt. Wilson in January last. At that time the insects were to be found in fair numbers on dark still evenings, and a beautiful sight they made, moving in lazy flight between the tree-ferns, their light alternately glowing and disappearing as they approached. This alternate emission and cessation of the phosphorescence appears to be characteristic of many species of Eastern fire-flies, and is supposed by von Siebold to coincide with the movements of inspiration and expiration. I observed that the gleams of light, both in flight and when the insect was at rest, lasted from about one-third to about two-thirds of a second, and that the intervals of darkness were of slightly longer duration; the light began as a feeble yellow glow, and gradually increased in intensity until it burst into a brilliant reddishyellow flame. As I have said, the fire-flies were common during

* Bull. Soc. Ent. Ital., xviii., p. 351 (1885); also J. R. Micr. Soc. (2) vI. p. 234 (1886).

t The idea that the "source of light" is withdrawn from the external wall of the luminous parts during the interval of darkness, and pressed against it during the period of light, put forward by Gorham (Tr. Ent. Soc. Lond., 1880, p. 66), is, of course, a mere assumption, and is opposed to the structure of the light-organs. 
my visit to Mt. Wilson, and I saw a considerable number of males flying together on more than one occasion, but I never saw the simultaneous cessation of light alluded to by many observers who have watched similar insect-swarms in South America and in the East.

The female of Atyphella is unfortunately unknown. It is, therefore, impossible at present to definitely decide upon the systematic position which the Mt. Wilson fire-fly should occupy. There are, as everybody knows, two groups of Lampyridæ which have the head hidden beneath the prothorax, one with the elrtra (wing-covers) and wings present in both sexes, the other with the elytra absent or rudimentary and the wings wanting in the female. In structure the male of Atyphella approaches certain forms which belong to the latter of these groups, but from this fact we have no right to assume that the female is apterous, although it is probable that this is the case. It would be most interesting to know the truth, and also to learn if the female is luminous like the male. Who is there to settle these questions? It may be that the females are winged, and remain quietly concealed in the grass, or beneath the leaves of the surrounding foliage, whilst the males indulge in flight, like the European species Luciola lusitanica, Char., alluded to by Dr. Sharp,* but I do not think this likely.

\section{A. Head completely hidden beneath prothorax (LAMPYRIN 2 ).}

Atyphella, gen. nov.

Elongate, sub-parallel. Head completely hidden by the prothorax, excavated between the eyes which are moderately large and prominent. Antennæ 11-jointed moderately robust, a little shorter than the prothorax, very slightly compressed, and somewhat narrowed at both extremities; the basal joint elongate, decidedly narrowed at the base, 2 nd joint about half as long as the 1st, 3rd longer and narrower than 2nd, joints 4-10 gradually

* Ent. Mo. Mag., xvir., p. 69 (1880). 
decreasing in length towards the extremity, and each slightly produced internally at the apex, terminal joint rather small, rounded anteriorly. Prothorax transverse, rounded in front, anterior margin strongly reflexed, the sides reflexed, subdiaphanous; the posterior margin reflexed, bisinuate. Scutellum elongate, rounded behind. Elytra elongate, rounded behind, each with four moderately elevated costæ; the margins strongly reflexed; the suture raised. Abdomen flattened, the posterior angles of the segments acute; beneath the whole of the last two segments are luminous, the terminal one gently bisinuate at the posterior margin and slightly produced in the middle; on each side, beyond the sinuations, the segment is feebly emarginate. Pygidium rounded behind. Legs moderately long; tarsi with the 4th joint strongly bilobed.

I have convinced myself by a careful examination of the genitalia, under a lens of suitable power, that all the specimens to which I have been able to refer belong to the one sex, and that the male. Under these circumstances it is not possible to decide the exact position of the genus with any degree of certainty, but I have little doubt of its near affinity to Diaphanes and Pyrocoelia, both divisions which have been made at the expense of the old genus Lampyris. The three Australian species I here propose to distinguish under the name Atyphella, are not characterized by any single point of structure (except perhaps the comparative length and form of the antennal joints) separating them from the many divisions of the Lampyridæ, but they present certain features which in combination seem to preclude their finding a place in any of the existing groups. None of the joints of the antennæ are strongly serrate, as joints 3-10 are said to be in Pyrocoelia.

I may add that Pyrocoelia bicolor, Fabr.,* described from "Nova Cambria," and said also to occur in Java, is unknown to

* This species is omitted in Masters' Catalogue of Australian Coleoptera, apparently by an oversight, as it is included in that of Gemminger and von Harold. The synonymy is as follows:-Lampyris bicolor, Fabr., 
me. Were it not that more than one writer since the time of Fabricius has recorded its occurrence in Australia, I should have thought there was some error in regard to the locality. It may be worth mentioning, as showing how easily an important omission in a description may escape the attention of systematic writers, that although Lampyris bicolor was redescribed by Boisduval in 1835, and its identity determined by Motschulsky (who referred it to the genus Cratomorphus), Gorham (who included it in his genus Pyrocoelia), and E. Olivier, its measurement has nowhere been recorded; on this point the only information we have is contained in the original description of Fabricius, who says "Magna in hoc genere (Lampyris)."

\section{Atyphella lychnus, sp.n.}

Elongate, pale fuscous, dusky testaceous at the sides, clothed with fine yellowish pubescence; prothorax coarsely and closely punctured, feebly bisinuate in front, and somewhat produced in the middle; each elytron with four conspicuous testaceous posteriorly abbreviated costæ.

Head excavated between the eyes; this excavation rugulosepunctate behind and at the sides, shining in the middle. Antennæ fuscous, moderately robust, 3rd joint elongate, decidedly narrowed at the base. Palpi testaceous. Prothorax broadly transverse, somewhat narrowed in front, moderately convex, fuscous, with the sides broadly testaceous, coarsely and closely rugulosepunctate; the anterior margin and sides strongly reflexed, the former gently bisinuate, and produced to an obtuse point in the middle; posterior margin strongly bisinuate, moderately strongly reflexed. Scutellum testaceous, finely and closely punctured. Elytra about four times as long as the prothorax, closely and moderately strongly rugulose-punctate, the suture and the narrow

Syst. El., II., p. 100 (1801); Boisd. Voy. Astrol., II., p. 129 (1835); Cratomorphus bicolor, Mots., Etud. Ent. p. 34 (1853); Pyrocoelia bicolor, Gorh., Trans. Ent. Soc. Lond. 1880, p. 91 ; E. Oliv., Notes Leyd. Mus., VIII., p. 199 (1886). 
up-turned lateral margins testaceous, each with four slightly raised costæ which are abbreviated before the apex; interstices broad; the 1st and 2nd costæ united, or with a tendency to unite, posteriorly. Underside piceous, except the prosternum, mesosternum, and the sides of the metasternum, which are duskytestaceous, and the last two abdominal segments and the genitalia, which are yellowish-white. Legs with the femora dusky testaceous ; the tibiæ and tarsi pale fuscous. Length $6 \frac{1}{2}-7 \frac{1}{2} \mathrm{~mm}$.

Mt. Wilson, Blue Mountains, N. S. Wales (3,478 feet), in January; and at Sydney, Kiama, \&c.

\section{o Unknown.}

I think it probable that this particular fire-fly, or one of its allies, is the "New Holland Species," which Carus, * as long ago as 1824, stated, on the authority of Long, to be possessed of a light which varies in intensity in "rhythmical vibrations."

A single Lampyrid larva found by me at Mt. Wilson in January, under some decaying wood is probably the young of A. lychnus. When it was captured it was in a very torpid state and showed no sign of luminosity, but I am assured by Mr. J. D. Cox, a careful observer who has passed many summers at Mt. Wilson, that a larva which he has found on several occasions and always regarded as the larva of the fire-fly, is faintly but distinctly phosphorescent, the light being continuous and not intermittent like that of the perfect insect. A comparison of my specimen (which is briefly described below) with those obtained by Mr. Cox has convinced me of their identity, so to say the least the evidence is strongly in favour of the assumption that these larvæ are the early stage of $A$. lychnus. It will be for future observers to determine if this is really the case by rearing the mature insect from these luminous larvæ.

Larva of A. Lychnus (?): Elongate, flattened, much narrowed both in front and behind, piceous, somewhat shining; the 1st thoracic and the last three abdominal segments rusty brown; the

* Oken's Isis, II., p. 245. 
intervening segments with two rows of inconspicuous reddish testaceous markings, one on each side of the middle; all segments (except the last) lobed at the sides and provided with a rather strongly impressed median channel, the edges of which are slightly raised; the margins very finely serrate.

Head completely hidden beneath the prothorax, corneous, narrowed and truncate in front; a large prominent ocellus on each side. Antennæ rather long, somewhat flattened, robust, placed at the sides of the head, 4-jointed, the 1st joint long, 2nd much shorter, slightly narrowed at the base, 3rd about twice as long as the $2 \mathrm{nd}$, obliquely truncate at the extremity, 4 th very minute, inserted in a groove at apex of 3rd near the internal angle. Mandibles prominent, falciform, and simple. Maxillæ elongate. Maxillary palpi short, robust, composed of three joints which gradually decrease in width towards the apex. Labial palpi 2jointed, minute. Near the base of each maxillary palpus is a minute apparently 2-jointed appendage.* First thoracic segment at the base about one-third broader than long, greatly narrowed in front; the anterior margin arched, strongly reflexed, slightly emarginate in the middle; the sides strongly reflexed, slightly sinuate on each side just behind the anterior angles, which are not very prominent; 2nd and 3rd thoracic segments short, about three times as broad as long, the sides reflexed, the angles rounded. Abdominal segments gradually narrowed to the apex, 1-7 like the segments of the thorax, 8th emarginate behind, 9th much narrower than the preceding, truncate. Beneath exceedingly finely granulate, the 1 st to 7 th abdominal segments provided on each side with a deeply impressed line, dividing the outer platelike portions from the middle of the segments. Stigmata nine pairs, two pairs placed on tubercles upon the meso- and metathoracic segments respectively, and seven upon tubercles within the plate-like divisions on the first seven segments of the abdomen. Legs rather short; claws simple. Length $9 \frac{1}{2} \mathrm{~mm}$.

* As I have no specimen for dissection I am not able to describe the mouth-structure as accurately as I could wish. 
This larva bears some resemblance to that of Photuris congrua, Chevr., described at considerable length by Chapuis (Hist. Mét. Col. Exot. p. 35, pl. 3, fig. 3, 1861), but the head is completely hidden when viewed from above, and the segments of the thorax (except the first) and body are more strongly lobed externally The three terminal segments of the latter are testaceous in colour, and probably it is from these that the phosphorescent light alluded to above will be found to proceed.

\section{A typhella scintillans, sp.n.}

Tolongate, dark fuscous, sparingly clothed with fine yellowish pubescence, prothorax coarsely and rather closely punctured, very feebly bisinuate in front, scarcely at all produced in the middle, with a median line on the disc; each elytron with four posteriorly abbreviated costæ.

Head very strongly excavated between the eyes; the excavation shining, finely punctured at the sides, with an obscure median ridge. Antennæ like those of $A$. lychnus, except that the terminal joint is a little larger. Prothorax moderately convex, fuscous, with the sides broadly testaceous, strongly and closely rugulose-punctate, with a distinct median line which is effaced both in front and behind; the anterior margin and sides moderately strongly reflexed, the former very feebly bisinuate, and slightly produced in the middle; posterior margin strongly bisinuate, moderately strongly reflexed. Scutellum testaceous, finely and closely punctured. Elytra very closely and moderately strongly rugulose-punctate, each with four costæ which are effaced posteriorly before reaching the apex, the interstices broad. Underside piceous, except the prosternum, mesosternum, and the sides of the metasternum which are dusky testaceous, and the genitalia and last two abdominal segments, which are yellowish white. Legs reddish testaceous, tibiæ darker, Length $7 \frac{1}{3}-8 \frac{1}{2} \mathrm{~mm}$.

Upper Hunter River, and Newcastle, New South Wales.

ㅇ Unknown. 
The ample and regularly rounded prothorax with its distinct median impression, and the deeply excavated head, are characters which combined with the form of the elytral costæ and its different colour, will at once distinguish this insect from the preceding species.

\section{Atyphella flammans, sp.n.}

Tे Elongate-ovate, fuscous, clothed with very fine yellowish pubescence ; prothorax pale testaceous, coarsely and closely punctured, with a large discal black marking very feebly bisinuate in front; elytra with the margins broadly testaceous, each with four posteriorly abbreviated costæ, the 1st and 2nd conspicuously testaceous, the 3rd faintly testaceous, the 4 th within the testaceous margin.

Head strongly excavated between the eyes, with a feeble elevation in front; the excavation shining, very finely rugulosepunctate at the sides. Antennæ fuscous, like those of A. lychnus, but with joints 4-10 proportionately Ionger. Palpi fuscous. Prothorax broadly transverse, rather strongly convex, with a large central black marking which is attenuated to a point behind ; the anterior margin and the sides strongly reflexed, the former very feeble bisinuate and slightly produced in the middle. Scutellum pale testaceous, closely and rather finely punctured. Elytra closely and moderately strongly rugulose-punctate, the suture testaceous and distinctly raised, the 1 st and 2nd costæ strongly elevated, reaching to just before the apex, the 3rd feebly elevated, effaced near the base, and abbreviated at about $\frac{2}{3}$ of the length of the elytra, the 4th costa rather feebly elevated, extending as far as the 1 st and $2 \mathrm{nd}$, the interstices broad. Underside dark piceous; the prosternum, mesosternum, and the sides of the metasternum dusky testaceous; the last two abdominal segments and the genitalia yellowish white. Legs fuscous; femora reddish testaceous. Length 9-10 $\mathrm{mm}$.

Cloncurry, Queensland.

ㅇ Unknown.

This species is conspicuous by the striped appearance of its elytra, and the black patch on its prothorax. 
B. Head received into, but not hidden by prothorax (LucIoLIN Æ). Luciola PUdica, sp.n.

Dark reddish fuscous, finely pubescent; head black; prothorax, scutellum, sterna, and legs (except the tibiæ and tarsi) reddish testaceous; abdomen bright yellow.

Head deeply excavated between the eyes; the excavation finely punctured, shining. Antennæ rather long, pubescent, the first two joints black, the others dark fuscous. Prothorax transverse, nearly quadrangular, finely and moderately closely punctured; feebly bisinuate both in front and behind; the anterior margin and the sides strongly, and the posterior margin moderately strongly reflexed, the former impressed on each side behind the upturned portion; an uninterrupted median line, and an indistinct impression on each side just behind the middle. Scutellum finely punctured. Elytra finely rugulose-punctate, the pubescence short and fine, closer than that of the prothorax, the suture slightly elevated, no distinct costæ, a faint indication of one near the base. Underside clear reddish testaceous; abdominal segments yellow, the apical one produced to a point in the middle, slightly sinuate on each side. Legs pale reddish testaceous; tibiæ darker, inclining to fuscous especially externally; tarsi fuscous. Length $6 \frac{1}{2}-8 \mathrm{~mm}$.

Bowen, Queensland ; New South Wales (A.M.).

I have examined six or eight specimens, all of which I believe to be males on account of the pointed form of the last abdominal segment; the species is evidently an ally of Luciola antennata, E. Oliv., * and L. australis, Fabr., but it is much smaller than the measurement indicated by Boisduval beside his very indifferent figure of the latter.

Two other species of the genus Luciola are known to me-the L. flavicollis, Macl., and what I regard as the L. dejeani, Gem., (apicalis, Boisd.), but as the single line of description submitted

* Ann. Mus. Genov. xxii. p. 365, pl. 5, fig. 8 (1885). 
as the diagnosis of $L$. apicalis by its founder is quite inadequate for the determination of a species in this or any other group, I am in some doubt as to the correctness of my conclusion. The only specimen I have seen was obtained during Sir T. L. Mitchell's Victoria River Expedition, but in what locality I have no knowledge. It is luteous, measures $9 \mathrm{~mm}$. in length, and is unusually robust, the elytra being nearly $4 \mathrm{~mm}$. in width at their middle; the head is black, the elytra (which have faint indications of four costæ) pitchy at the apex; beneath the last two segments are yellowish-white (apical one rounded behind, very slightly produced in the middle), the preceding segment margined with piceous posteriorly; tarsi and tips of the tibiæ fuscous.

L. flavicollis has well marked sexual characters which may be defined as follows :-

f Abdomen with penultimate segment and a semicircular basal spot on apical segment luminous; the apical segment deeply emarginate on each side, very strongly produced between the emarginations, the produced portion with nearly parallel sides, the apex feebly emarginate. Eyes very large.

o Abdomen with penultimate segment luminous, apical segment feebly emarginate in the middle; small supplementary segment rounded behind, complete. Eyes moderately large.

By the light of additional material which I have seen from Rockhampton and Port Curtis, Queensland, I am in a position to affirm that the suture in this species, like the sides, is luteous to within a short distance of the apex.

I am informed by those who are acquainted with the haunts of $L$. flavicollis that its light is intermittent. 


\section{$2 \mathrm{BHL}$ Biodiversity Heritage Library}

Olliff, Arthur Sidney. 1890. "New species of Lampyridae, including a notice of the Mt. Wilson fire-fly." Proceedings of the Linnean Society of New South Wales 4, 643-653. https://doi.org/10.5962/bhl.part.15062.

View This Item Online: https://www.biodiversitylibrary.org/item/29780

DOI: https://doi.org/10.5962/bhl.part.15062

Permalink: https://www.biodiversitylibrary.org/partpdf/15062

\section{Holding Institution}

MBLWHOI Library

\section{Sponsored by}

MBLWHOI Library

\section{Copyright \& Reuse}

Copyright Status: NOT_IN_COPYRIGHT

This document was created from content at the Biodiversity Heritage Library, the world's largest open access digital library for biodiversity literature and archives. Visit BHL at https://www.biodiversitylibrary.org. 